\title{
Analysis of the Effect of Waste Bank Program on Empowerment of Poor Women in Kelurahan Sicanang Belawan Medan
}

\author{
Mujahiddin, ${ }^{1}$ Yurisna Tanjung, ${ }^{2}$ \& Efendi Augus ${ }^{3}$ \\ Social Welfare Department, University of Muhammadiyah Sumatera Utara(UMSU), Indonesia \\ email: mujahiddin@umsu.ac.id
}

\begin{abstract}
The existence of socio-economic benefits generated from waste savings makes the role of waste banks not only limited to waste management and recycling. But the waste bank is also able to increase participation, skills and changes in the attitude of the poor in waste management, especially women who are always involved in the household scale waste management process. On the basis of this, it is important to see the influence of the waste bank on the empowerment of poor women in Sicanang Belawan, Medan. This study uses several theoretical descriptions and related concepts; Garbage Bank and Community Empowerment Program. This research design uses associative research methods with a quantitative approach. This approach is deliberately chosen because to be able to find out the influence and also the relationship between the waste bank program variables and the empowerment of poor women. In this study, the sampling technique uses Harry King's Nomogram, where the total customers of 10 waste banks are 200 customers. Of the 200 customers taken samples with a 5\% error rate. So that the number of samples to be examined is 30 customers. Then, 30 of these customers are evenly distributed to each bank of waste banks. So there are 3 customers to represent each waste bank. The results showed, first; The Waste Bank program partially has a significant influence on the empowerment of poor women. This can be seen from the value of Sig $=0.000$ which is smaller than $\alpha 0.05$. In addition, the $R$ Square value is 0.472 . which means that $47.2 \%$ of the variation in the variables of empowerment of women can be influenced by the variables of the waste bank program. Second; there is a positive and strong relationship between the Waste Bank Program and Poor Women's Empowerment of $r=0.687$.
\end{abstract}

Keywords: waste; empowerment; poor women; bank program

\section{Introduction}

Garbage has been defined as something or material that has no use value or benefits socially and economically so it must be discarded. In Law No. 18 of 2008 concerning waste management, waste is defined as the remainder of human daily activities and / or solid natural processes. Azwar in Simanungsong (2003) also defines the same thing, namely that waste is considered as something that is not used, not liked or something that must be discarded, which generally comes from activities carried out by humans (including industrial activities) but which are not biological (because of human waste not included in it) and generally solid.

Negative definition of waste makes waste into one item or material that is considered useless so that it never gets proper treatment through the recycling process. That is why waste production to the landfill continues to increase from year to year because the waste produced by individuals on a household scale has never received adequate recycling treatment so that 
the waste produced is directly stacked in each landfill. Mujahiddin (2016) noted in 2011 - as he quoted from BPS and other news sources - the production of waste produced by 380 cities in Indonesia reached 80,000 tons per day. It is estimated that by 2025 the amount of waste produced in Indonesia will reach 130,000 tons per day. When viewed specifically, in the city of Medan for example, in 2013 the volume of waste produced every day by the people of Medan City ranged from 1700 tons. If totaled every month the waste produced by the people of Medan City reaches 44,000 tons and 85 percent of the amount of waste is transported directly to the Final Disposal Site (TPA) without going through the process of sorting and recycling. Continuous accumulation of garbage in the TPA will certainly have a negative effect on environmental sustainability. Especially in Medan City the form of TPA is still using an open dumping system which is considered the simplest and cheapest TPA system. In the landfill with an open dumping system, garbage will be piled up and stacked continuously until it is like a hill or mountain. Sinulingga (2005) notes that the dumping of waste with this type of open dumping is only suitable for trash from road sweeps, ash and objects that can be burned. But when mixed with other waste such as organic waste, this trash can will be a source of environmental pollution such as bad odor, fire or garbage explosion - like the tragedy in Bandung Leuwigajah Landfill - and the other result is the decay of waste and will cause waste liquid (leachate) which can be a source of disease. Whereas if the waste is reprocessed through a recycling mechanism, then the waste that is considered to have no use value will be able to be reused as one item that has normal function. Mujahiddin (2014) in his thesis research explained that the process of recycling waste to become useful goods provides many benefits for the community. Organic waste can be recycled into fertilizer for plants.

Whereas inorganic waste such as plastic leftover packaging can be recycled into shopping bags, wallets, drink bases and plastic flowers. Garbage from the rest of the newspaper is processed into baskets and decorative flower pots. All goods from the processed waste can not only be used for personal purposes but can also be sold .Besides being recyclable, waste can also be saved and converted into rupiah units. This garbage saving mechanism can be seen from the waste bank-based waste management model. In a waste bank, dry or inorganic waste produced from household scale can be saved by sorting or classifying waste based on its type, for example; plastic waste that is combined with plastic waste, paper waste that is combined with paper waste, glass waste that is combined with glass waste and so on. Through this sorting process, in fact the waste bank has taught a culture of sorting trash for people who are active as waste bank customers. Not only that, the waste bank through a garbage savings program can also provide socio-economic benefits for the community, especially poor families. Mujahiddin and Ananda (2017) explained that there are two benefits of waste saving for poor families in Sicanang Belawan Medan, namely; economic benefits and social benefits. Economic benefits are indicated by the addition of family income from the results of waste savings. This additional income is mostly used by poor families to study family food needs. Besides that it is also used for the purposes of financing their children's needs which include; snacks for school, buying children's school equipment and transportation costs. While social benefits are seen from changes in community behavior in managing waste which include; behavior of sorting garbage, increasing participation in waste management and increasing skills in recycling waste. The existence of socio-economic benefits generated from waste savings makes the role of waste banks not only limited to waste management and recycling. But the waste bank is also able to increase participation, skills and changes in the attitude of the poor in waste management, 
especially women who are always involved in the household scale waste management process. On the basis of this, it is important to see the influence of the waste bank on the aspect of empowering poor women. Because, with the empowerment of women's groups in managing waste that is sorting or recycling - it is hoped that it can put the brakes on waste production to the landfill and be able to help families increase their income through waste savings. So that the waste produced by individuals on a household scale can be reused. Based on the description above, this study will analyze the Effect of Garbage Bank Programs on the Empowerment of Poor Women in Sicanang Belawan Village, Medan.

\subsection{Formulation of Problems}

Problems in this study are formulated as follows:

1. Is there any effect of the waste bank program on empowering poor women in Sicanang Belawan Village, Medan?

2. How does the relationship between the waste bank program and the empowerment of poor women in the Sicanang Belawan Village Medan be improved?

\section{Methods of The Research}

\subsection{Research Design}

This research design uses associative research methods with a quantitative approach. This approach was deliberately chosen because to be able to find out the influence and also the relationship between the variables of the waste bank program and community empowerment. As Sugioyono (2010) said, the formulation of an positive problem is a formulation of a research problem that asks questions about the relationship between two or more variables.

\subsection{Research Samples}

In this study, the sampling technique will use Harry King's nomogram, where the total customers of the 10 waste banks are 200 customers. Of the 200 customers, samples will be taken with a $5 \%$ error rate so that the number of samples to be examined is 30 customers. Then, 30 of these customers are divided equally among each waste bank. So there are 3 customers to represent each waste bank.

\subsection{Techniques Analysis Data}

Data that has been collected through a questionnaire or quisioner will be analyzed in two stages, namely, first; To answer the research problem formulation related to the effect of the Waste Bank Program on Community Empowerment, the data will be analyzed by simple regression analysis. Second, to see how fast the relationship between the waste bank program and the empowerment of poor women is, the data will be analyzed using the Pearson Correlation approach. All data that will be analyzed will be analyzed using SPSS 17.0-based statistics by looking at the influence and relationships between variables. Where the Waste Bank Program is defined as a variable (X), and Community Empowerment as a variable (Y). 


\section{Theoretical Description}

\subsection{Waste Bank Program}

Garbage banks are one of several concepts or models of waste management. Suwerda (2012) defines waste management carried out by the community today into four types namely; (1) Management of household waste with traditional systems. (2) Management of household waste with a collect-transport-waste system. (3) Waste management with an independent and productive system and (4) waste management with waste savings in a waste bank. This waste management model through a waste bank is a manifestation of waste management efforts by applying the 3-R principle (Reduce, Reuse, Recycle). In the waste bank, the system implemented is a system of managing waste and accommodating, then sorting and distributing waste to other waste processing facilities or to those in need. Here the value of the use of goods that have become garbage can be increased, which was previously useless into useful items. In addition, the collection and processing of waste by distributing it to other waste processing facilities or to those in need can also help reduce the intensity of garbage disposal to the TPS or TPA. Judging from its understanding, Utami (2013) explained that waste banks can be said to be a collective dry waste management system that encourages people to actively participate in them. This system will accommodate, sort and distribute economic value waste to the market so that people get economic benefits from saving waste.

So all activities in the waste bank system are carried out from, by and for the community. The waste deposited by the customer must be sorted. This requirement encourages people to separate and classify waste. For example, based on the type of material; plastic, paper, glass and metal. So, the waste bank will create a new culture so that people want to sort waste. Thus, the waste bank system can be used as a tool for social engineering.

So that a better order or system of waste management is formed in the community (Utami, 2013). The presence of waste banks in several cities in Indonesia is expected to be able to provide meaningful benefits for the community. Suwerda (2012) notes that there are four benefits that can be expected from the presence of a waste bank as a waste management model. Waste banks - existing waste banks are then expected to be beneficial for; first, environmental health. Second, socio-economic community. Third, the education aspect and fourth, for the government. For environmental health, the presence of a waste bank is expected to be able to create a clean and healthy environment, reducing the habit of burning garbage and hoarding garbage. Whereas for socio-economic aspects, waste banks are expected to be able to increase family income from waste savings, and also can build good social relations between communities. For the education aspect, the presence of a waste bank is expected to change the habits of the community in managing the waste they produce. With the existence of a waste bank, the community is expected to be able to sort garbage from home before being saved to a waste bank. In addition, the existence of waste savings is also expected to instill the importance of saving for the community. Finally, the presence of a waste bank is expected to benefit the government, especially in the waste management business. Garbage banks can be used as an alternative for waste management. Another benefit that is generated from waste banks and waste savings is to be a mechanism to drive change in people's lives. This was revealed from the results of research conducted by Syafrini (2013) in which at one point the study concluded that concluding that wife or housewife who had not worked, after becoming a waste bank customer had a job opportunity to produce plastic waste into economically valuable objects. whose results can help increase the family's economic 
needs. For waste savings, Syafrini (2013) explains that the balance stated in the customer's savings, adjusted to the weight of the collected waste per item which is then calculated at a predetermined price. This means that the more waste is brought, the more money is saved, even though once they save waste, not much money is generated, only around Rp. 3,000 to Rp. 35,000, - for saving once. However, according to the customers with this profit, they are more eager to collect household waste and even outside the garbage seen on the streets or in the office, they often bring it home with the hope of being saved.

\subsection{Community Empowerment}

In Indonesia the term community empowerment as a translation of the word "empowerment" began to be used in everyday language along with the term "poverty alleviation"(proverty alleviation) which was marked by the issuance of Presidential Instruction No. 5/1993 which was later better known as the Disadvantaged Village Instruction (IDT). Since then, the terms empowerment and poverty alleviation are "twin brothers" which have always been the topic and key words of development efforts (Mardikanto, 2012). Not surprisingly, then most of the definition of empowerment emphasizes the importance of someone to get the ability and control over resources that determine a person's quality of life.

Some authors emphasize the definition of empowerment at different levels, both personal, which includes a person's confidence and abilities; relational, which emphasizes the ability to negotiate and influence relationships and decisions; and at the collective level. Ife and Tesoriero (2008) for example; means empowerment as the provision of resources, opportunities, vocabulary, knowledge and skills to improve the ability of the community to determine their own future and to participate and influence the lives of their people. This understanding shows that empowerment is an increase in the ability of the community to be independent, control its future and also the ability to influence others. So empowerment is not just to help the poor so that they are not poor but more than that, which is to give strength to the poor by increasing their ability to be independent or empowered. Therefore, empowerment can be used for different goals and targets according to the needs of the community. For example, in the context of this research, empowerment certainly refers to the improvement of the economy of the poor through waste management that is carried out independently. This empowerment effort will be measured whether the existence of a waste bank program can empower the poor in managing waste independently. This independence is defined as the ability to sort, recycle and utilize waste as an asset. This is in accordance with what Parson said as quoted by Suharto (2004) that empowerment can also be interpreted as a process by which people become strong enough to participate in sharing control, affecting events and institutions that affect their lives. Empowerment emphasizes that people acquire sufficient skills, knowledge and power to influence the lives and lives of others who concern them.

\section{Results And Discussion}

The discussion of this research will be focused on answering two formulations of the research problem, namely; 
1. Is there any effect of the waste bank program on empowering poor women in Sicanang Belawan Village, Medan?

2. How does the relationship between the waste bank program and the empowerment of poor women in the Sicanang Belawan Village Medan be improved?

The first point in the formulation of the problem above will be answered using simple regression analysis through the SPSS 17.0 application. This is in accordance with what was said by Khadir (2016), namely; Simple regression analysis studies whether between two or more variables has an influence / relationship or not, measures the strength of its influence and makes predictions based on strong or weak influences / relationships. Whereas for the second point in the problem formulation will be answered by using Pearson Correlation analysis through SPSS 17.0 application.

\subsection{Effect of Garbage Bank (X) on Empowering Poor Women (Y)}

\section{$>$ Partial Testing ( $\mathrm{t}$ Test)}

The $t$ test is used to determine whether the independent variable (Waste Bank Program) partially has an effect on or not on the dependent variable (Community Empowerment). To measure that, a degree of significance or a confidence level of 0.05 is determined. If the significant value is smaller than the degree of trust, it can be said that the independent variable partially affects the dependent variable. Testing of the influence of independent variables or the Waste Bank Program (X) on the dependent variable or Poor Women's Empowerment (Y) can be seen in Table 5.1 below.

Table 1. Partial Test $X$ Against $Y a$

\begin{tabular}{|c|c|c|c|c|c|c|}
\hline & \multirow{2}{*}{ Model } & \multicolumn{2}{|c|}{ Unstandardized Coefficients } & $\begin{array}{c}\text { Standardized } \\
\text { Coefficients }\end{array}$ & \multirow{2}{*}{$\mathrm{t}$} & \multirow{2}{*}{ Sig. } \\
\hline & & B & Std. Error & Beta & & \\
\hline \multirow{2}{*}{1} & (Constant) & 15.687 & 7.403 & & 2.119 & .043 \\
\hline & Waste Bank Program & 446 & 089 & 687 & 5.004 & .000 \\
\hline
\end{tabular}

a. Dependent Variable: Empowering Poor Women

Based on table 5.51 above obtained t count equal to 5.004 with Sig. .000 is smaller than $\alpha 0.05$. This means that the Waste Bank Program (X) partially has a significant influence on Poor Women's Empowerment (Y). A positive $t$ value indicates that the waste bank program variable has a direct relationship with the empowerment of poor women in Sicanang Belawan Medan. So it can be concluded that the waste bank program has a significant influence on the empowerment of poor women. In addition, in table 5.1 above can also be seen the estimated value of the Waste Bank Program variable coefficient of 0.446 points, which means that each addition of 1 value in the waste bank program will add value to the empowerment of poor women in Sicanang Belawan at 0.446 points.

\section{Simultaneous / Total Testing (F Test)}

The $\mathrm{F}$ test is used to determine whether the independent variables simultaneously significantly influence the dependent variable. 
Table 2. $F X$ Test Against $Y b$

\begin{tabular}{|c|c|c|c|c|c|c|}
\hline \multicolumn{1}{|c|}{ Model } & Sum of Squares & Df & Mean Square & F & Sig. \\
\hline \multirow{4}{*}{1} & Regression & 209.107 & 1 & 209.107 & 25.036 & $.000^{\mathrm{a}}$ \\
& Residual & 233.860 & 28 & 8.352 & & \\
& Total & 442.967 & 29 & & & \\
\hline
\end{tabular}

a. Predictors: (Constant), Waste Bank Program

b. Dependent Variable: Empowering Poor Women

The significance test of the regression line equation is obtained from the 5 th Regression column row, which is $\mathrm{F}$ hit $(\mathrm{b} / \mathrm{a})=25,036$ and $\mathrm{p}$-value $=0,000<0,05$. Thus the regression of Y (Poor Women's Empowerment) on X (Waste Bank Program) is significant or the waste bank program influences the empowerment of poor women.

Determination Coefficient (R2)

Table 3. R Square (Model Summary X - Y)

\begin{tabular}{|c|c|c|c|c|c|c|c|c|c|}
\hline \multirow[b]{2}{*}{ Model } & \multirow[b]{2}{*}{$\mathrm{R}$} & \multirow{2}{*}{$\begin{array}{c}\mathrm{R} \\
\text { Square }\end{array}$} & \multirow{2}{*}{$\begin{array}{c}\text { Adjuste } \\
\text { dR } \\
\text { Square }\end{array}$} & \multirow{2}{*}{$\begin{array}{l}\text { Std. Error of } \\
\text { the Estimate }\end{array}$} & \multicolumn{5}{|c|}{ Change Statistics } \\
\hline & & & & & $\begin{array}{l}\text { R Square } \\
\text { Change }\end{array}$ & F Change & df1 & df 2 & $\begin{array}{c}\text { Sig. F } \\
\text { Change }\end{array}$ \\
\hline 1 & $.687^{\mathrm{a}}$ & .472 & .453 & 2.89001 & .472 & 25.036 & 1 & 28 & .000 \\
\hline
\end{tabular}

a. Predictors: (Constant), Waste Bank Program

The coefficient of determination is used to find out how much the relationship of the variable is in a clearer sense. The coefficient of determination will explain how much change or variation in other variables. In this case, it attempts to explain how much change or variation of the Waste Bank Program variable on variations in the variable Poor Women's Empowerment. In table 5.3 can be seen the number of $\mathrm{R}$ Square is 0.472 . Thus it can be concluded that $47.2 \%$ of the variation in the variables of empowering poor women can be influenced by the variables of the waste bank program. While the rest is influenced by other variables not examined in this study.

\section{2. Degree of Relationship between Waste Bank Program (X) with Poor Women's Empowerment (Y)}

Table 4. Degree of Relationship Between the Waste Bank and Poor Women's Empowerment Programs 


\begin{tabular}{|cc|c|c|}
\hline & & Waste Bank Program & $\begin{array}{c}\text { Community } \\
\text { empowerment }\end{array}$ \\
\hline Waste Bank Program & Pearson Correlation & 1 & $.687^{* *}$ \\
& Sig. (2-tailed) & & .000 \\
& $\mathrm{~N}$ & 30 & 30 \\
\hline Poor Women's & Pearson Correlation & $.687^{* *}$ & 1 \\
Empowerment & Sig. (2-tailed) & .000 & 30 \\
\hline
\end{tabular}

**. Correlation is significant at the 0.01 level (2-tailed).

The estimation results of the correlation between the Waste Bank Program and Poor Women's Empowerment are $r=0.687$. This value shows that there is a positive and strong relationship between the Waste Bank Program and Poor Women's Empowerment.

\section{Conclusion}

The conclusions in this study are as follows:

1. The Waste Bank program partially has a significant influence on the empowerment of poor women. This can be seen from the value of $\mathrm{Sig}=0.000$ which is smaller than $\alpha$ 0.05 . In addition, it can also be seen that the $\mathrm{R}$ Square value is 0.472 . Which means that $47.2 \%$ of the variation in the variables of female empowerment can be influenced by the waste bank program variables. While the estimation results of the Waste Bank Program variable coefficient is 0.446 , which means that every addition of 1 Waste Bank Program will add value to the empowerment of poor women in Sicanang Belawan at 0.446 points.

2. The relationship between the Waste Bank Program and the Empowerment of Poor Women by $r=0.687$. This value shows that there is a positive and strong relationship between the Waste Bank Program and Poor Women's Empowerment.

\section{References}

BPS Kota Medan. 2009, 2010, 2011, 2012. Medan Dalam Angka. Medan: BPS Kota Medan.

Ife, Jim. Frank Tesoriero. (2008). Community Development; Alternatif Pengembangan Masyarakat di Era Globalisasi. (Edisi Ketiga). Yogyakarta: Pustaka Pelajar

Khaidir, Dr. M.Pd. (2016). Statistik Terapan; Konsep, Contoh dan Analisis Data Dengan Program SPSS/Lisrel dalam Penelitian. Edisi Kedua. Jakarta: RajaGrafindo Persada

Mardikanto, Totok. Poerwoko Soebiato. 2012. Pemberdayaan Masyarakat; Dalam Perspektif Kebijakan Publik. Bandung: Alfabeta.

Mujahiddin, S.Sos, MSP, H. 2016. Upaya Pemberdayaan Masyarakat Dalam Mengelola Sampah. Medan: 'nBasis.

Sinulingga, D. Budi. 2005. Pembangunan Kota; Tinjauan Regional dan Lokal. Jakarta: Pustaka Sinar Harapan. 
Suharto, Edi. 2004. Pendekatan Pekerjaan Sosial Dalam Pemberdayaan Masyarakat Miskin: Konsep, Indikator dan Strategi. Malang.

Sugiyono. 2010. Metode Penelitian Kuantitatif, Kualitatif dan R\&D. Bandung: Penerbit Alfabeta.

Suwerda, Bambang. 2012. Bank Sampah; Kajian Teori dan Penerapan). Yogyakarta: Pustaka Rihama.

Utami, Eka. 2013. Buku Panduan Sistem Bank Sampah \& 10 Kisah Sukses. Jakarta: Yayasan Unilever Indonesia.

Sumber Jurnal \& Thesis:

Dodon. 2013. Indikator dan Perilaku Kesiapsiagaan Masyarakat di Permukiman Padat Penduduk Dalam Antisipasi Berbagai Fase Bencana Banjir. Jurnal Perencanaan Wilayah dan Kota Vol 24 No 2, hlm 125 - 140.

Mujahiddin dan Ananda Mahardika. 2017. The Benefit of Waste Bank for Poor Families in Sicanang Belawan, Medan, North Sumatra. IOSR Journal of Humanities and Social Science. Vol 22, Issue 3, Ver VII. March 2017. PP 37-43.

Mujahiddin. 2014. Upaya Pemberdayaan Masyarakat Dalam Mengelola Sampah Anorganik Melalui Bank Sampah (Studi Kasus: Di Bank Sampah Simpan Jadi Mas Lingkungan V Blok B Lorong II Kelurahan Belawan Sicanang Kecamatan Medan Belawan). Tesis. Medan: Program Studi Magister Studi Pembangunan Fakultas Ilmu Sosial dan Ilmu Politik Sumatera Utara.

Simangungsong, Rahidun. 2003. Analisis Partisipasi Masyarakat Terhadap Program Kebersihan Sampah Di Kota Pematang Siantar. Tesis. Medan: Program Pasca Sarjana Universitas Sumatera Utara.

Syafrini, Delmira. 2013. Bank Sampah: Mekanisme Pendorong Perubahan Dalam Kehidupan Masyarakat, Studi Kasus; Bank Sampah Barokah Assalam Perumahan Dangau Teduh Kecamatan Lubuk Begalung, Padang. Jurnal Humanus. Vol. XII. No. 2 Thn 2013.

\section{Constitution}

Republic of Indonesia Law No. 18 of 2008: About Waste Management.

Republic of Indonesia Law No. 52 of 2009: Concerning Population Development and Family Development. 